DOI: https://doi.org/10.24127/ajpm.v10i1.3173

\title{
MATHEMATICAL CONCEPT UNDERSTANDING ABILITY AND SELF-REGULATED LEARNING: THE EFFECT OF QUICK ON THE DRAW STRATEGY
}

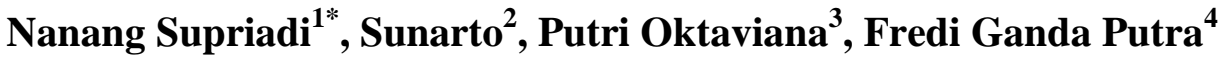 \\ ${ }^{1 *, 3,4}$ UIN Raden Intan Lampung, Bandar Lampung, Indonesia \\ ${ }^{2}$ UIN Sulthan Thaha Saifuddin Jambi, Kota Jambi, Indonesia \\ *Corresponding author. Jl. Letkol Endro Suratmin Sukarame, 35131, Bandar Lampung, Indonesia. \\ E-mail: $\quad$ nanangsupriadi@radenintan.ac.id ${ }^{1 *}$ \\ sunarto0114@yahoo.com ${ }^{2)}$ \\ putrioktviana@gmail.com ${ }^{3)}$ \\ fredigpsw@radenintan.ac.id ${ }^{4)}$
}

Received 20 October 2020; Received in revised form 08 March 2021; Accepted 31 March 2021

\begin{abstract}
The mathematical concept understanding ability and self-regulated learning in mathematics need to be mastered by students to support them in the learning process and solving various mathematical problems. This research aimed to determine the effect of the Quick on the Draw strategy on students' mathematical concepts understanding and self-regulated learning. The sample of this research consisted of fifty-six students, specifically twenty-nine students in the experimental class and twenty-seven students in the control class. Furthermore, this research employed the quasi-experimental with a $2 \times 2$ factorial research design. The research data that had been collected through tests and questionnaires were tested for their normality and homogeneity. The research hypothesis was tested using the Multivariate Analysis of Variance (MANOVA). Based on the results of research and data analysis, it can be concluded that there was an effect of the Quick on the Draw strategy on students' mathematical concept understanding ability and self-regulated learning.
\end{abstract}

Keywords: Mathematical concept understanding; self-regulated learning; quick on the draw strategy.

\begin{abstract}
Abstrak
Kemampuan pemahaman konsep matematis dan self-regulated learning dalam pembelajaran matematika merupakan suatu kemampuan yang perlu dikuasai oleh setiap peserta didik guna menunjang peserta didik dalam proses belajar dan menyelesaikan berbagai permasalahan matematika. Penelitian ini bertujuan untuk mengetahui pengaruh penerapan strategi pembelajaran Quick on the Draw terhadap kemampuan pemahaman konsep matematis dan self-regulated learning peserta didik. Penelitian ini menggunakan sampel sebanyak 56 siswa (kelas eksperimen $n=29$ dan kelas kontrol $n=27$ ) dengan jenis penelitian Quasy Eksperimental Design dengan rancangan penelitian faktorial $2 \times 2$. Teknik pengumpulan data dalam penelitian ini berupa angket dan tes. Teknik analisis data yang digunakan yaitu uji Normalitas dan uji Homogenitas. Pengujian hipotesis dalam penelitian ini menggunakan Uji Multivariate Analysis of Variance (MANOVA). Berdasarkan hasil penelitian dan perhitungan uji Manova, diperoleh kesimpulan bahwa terdapat pengaruh penerapan strategi pembelajaran Quick on the Draw terhadap kemampuan pemahaman konsep matematis peserta didik. Terdapat pengaruh penerapan strategi pembelajaran Quick on the Draw terhadap self-regulated learning peserta didik. Terdapat pengaruh penerapan strategi pembelajaran Quick on the Draw terhadap kemampuan pemahaman konsep matematis dan self-regulated learning peserta didik.
\end{abstract}

Kata Kunci: Pemahaman konsep matematis; self-regulated learning; strategi quick on the draw.

This is an open-access article under the Creative Commons Attribution 4.0 International License. 


\section{INTRODUCTION}

Mathematical concept understanding ability helps students to face and solve mathematical problems (Diana, Marethi, \& Pamungkas, 2020). The mathematical concept understanding ability in the mathematics learning process can assist students in selecting a complete design and ease them to correctly conclude concepts (Inayatusufi, Hakim, \& Sari, 2020; Ntjalama \& Murdiyanto, 2020). Concept mastery allows students to acquire complete new knowledge (Winata \& Friantini, 2020).

Concept understanding ability requires students to commit to a meaningful method of learning that is more than just memorizing (Sukaesih, Indiati, \& Purwosetiyono, 2020) and manage and organize themselves in learning (Sundary, Jatmiko, \& Widyastuti, 2020). Students' selfmanagerial and organizational ability in learning is the very definition of selfregulated learning (Utami, Ramdani, \& Khusaini, 2020). Mathematics selfregulated learning can hone students' conceptual understanding (Subekhi \& Pujiastuti, 2020).

Self-regulated learning is beneficial in developing students' potential knowledge and skills to meet their learning objectives (Hudaifah, 2020). Students with good self-regulated learning act enthusiastically and never give up (Hodiyanto \& Firdaus, 2020). Students can recognize themselves, understand how they like to learn, and use their strengths to overcome difficulties during the learning process through self-regulated learning (Alten, Phielix, Janssen, \& Kester, 2020; Jansen, Leeuwen, Janssen, \& Jak, 2019). Each student can have different self-regulated learning based on their environmental conditions (Mulyati \& Setiawan, 2019). When self-regulated learning is successfully developed, learning objectives become more focused (Prameswari \& Anistyasari, 2019). Thus, self-regulated learning in mathematics is necessary to support the learning process.

The accuracy in selecting learning strategies is an effort to improve the mathematical concept understanding and self-regulated learning. The cooperative learning strategy used to enhance the abilities is the Quick on the Draw strategy.

Several studies on the Quick on the Draw strategy reveal that the strategy is effective to increase learning motivation (Huriyanti \& Rosiyanti, 2017), learning activities and outcomes (Aini \& Irawati, 2019), and improving students' mathematical communication skills (Damayanti, Zulkarnain, \& Sari, 2020). Other research reveals that the STEM learning model (Sagala, Umam, Thahir, Saregar, \& Wardani, 2019), the metaphorical thinking learning model (Sundary et al., 2020), and the guided discovery approach (Romadon \& Mahmudi, 2019) can improve conceptual understanding. Besides mathematical concept understanding, the self-regulated learning ability has also been studied before. The results show that selfregulated learning can be enhanced by applying the STEM model (León, Núñez, \& Liew, 2014) and Creative Solution Focused Counseling Models (Saputra, Da Costa, \& Alhadi, 2018).

Based on the results of previous research, many researchers have implemented the Quick on the Draw learning strategy. However, no researchers have implemented the strategy to see its effects on mathematical concept understanding ability and self-regulated learning, either partially or simultaneously. Thus, this research will specifically discuss the 
results of the Quick on the Draw learning strategy on mathematical concept understanding ability and selfregulated learning.

\section{METHODS}

Because the data collected in this research was in the form of quantity (numbers), it is classified as quantitative research. This research employed the posttest only quasi-experimental group design with a $2 \times 2$ factorial research design. The population in this research was all SMPN (State Junior High School) students in Bandar Lampung. The sample in this research consisted of fifty-six students (29 in the experimental class and 27 in the control class) determined by cluster random sampling technique. The stages of the Quick on the Draw strategy are presented in Figure 1.

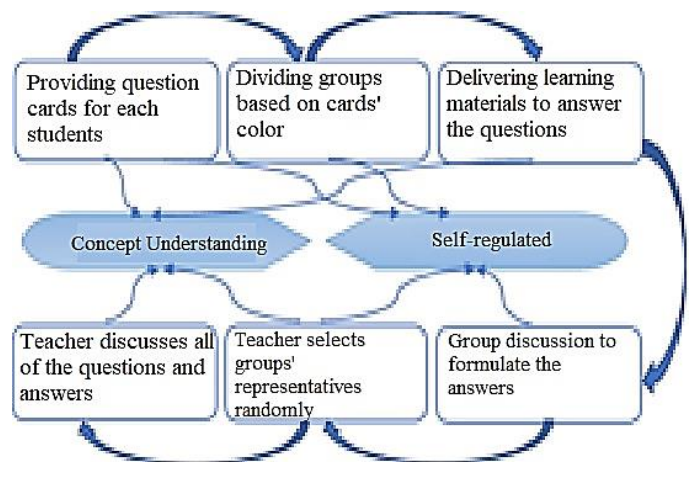

Figure 1. The stages quick on the draw learning strategy

Figure 1 displays the six stages of the Quick on the Draw strategy: 1) preparing a card containing questions for each student, 2) dividing groups based on the color of the cards, 3) providing material to answer questions, 4) holding group discussion to formulate answers, 5) selecting group representatives randomly, and 6) discussing all questions and answers. This learning model can train the mathematical concept understanding ability and selfregulated learning. The first, third, fifth, and sixth stages are for training mathematical concept understanding ability, while the first, second, third, and fifth stages are for training the selfregulated learning.

The data of mathematical concept understanding ability were collected using tests, and the data of self-regulated learning were collected using a questionnaire. The data were analyzed using Multivariate Analysis of Variance (MANOVA) with a critical value of $\alpha=$ $5 \%$.

\section{RESULTS AND DISCUSSION}

After the treatments had been completed, the data of students' mathematical concept understanding, and self-regulation learning were also obtained. The data from the experimental class (Quick on the Draw strategy) and the control class (conventional learning strategy) are presented in Table 1.

Table 1 . Test results analysis on students' mathematical concept understanding

\begin{tabular}{|c|c|c|c|c|c|c|c|}
\hline \multirow{2}{*}{ Value } & \multirow{2}{*}{$X_{\max }$} & \multirow{2}{*}{$X_{\min }$} & \multicolumn{3}{|c|}{ Central Tendency } & \multicolumn{2}{|c|}{$\begin{array}{c}\text { Group } \\
\text { Variance }\end{array}$} \\
\hline & & & $\bar{X}$ & $\mathbf{M}_{\mathbf{e}}$ & $\mathbf{M}_{\mathbf{o}}$ & $\mathbf{R}$ & $\mathbf{S}$ \\
\hline Experimental Class & 100 & 45 & 83.8 & 86 & 83 & 55 & 14.98 \\
\hline Control Class & 74 & 50 & 70.5 & 74 & 50 & 45 & 13.91 \\
\hline
\end{tabular}

Table 1 reveals that the experimental class that implemented the Quick on the Draw learning strategy had a better conceptual understanding than the control class, proven by the mean value $(\underline{X})$ of 88.8 and the mode 
value $\left(\mathrm{M}_{\mathrm{o}}\right)$ of 86 . However, the obtained range values were quite large compared to the control class. These results indicated that the difference between the highest and the lowest scores in the Quick on the Draw learning strategy was relatively high. Therefore, it can be concluded that the mathematical concept understanding ability in the experimental class was better compared to the control class. The results of the self-regulated learning questionnaire are presented in Table 2 .

Table 2. The Self-Regulated Learning Questionnaire Data

\begin{tabular}{|c|c|c|c|c|c|c|c|}
\hline \multirow{2}{*}{ Value } & \multirow{2}{*}{$\mathbf{X}_{\max }$} & \multirow{2}{*}{$\mathbf{X}_{\min }$} & \multicolumn{3}{|c|}{ Central Tendency } & \multicolumn{2}{|c|}{ Group Variance } \\
\hline & & & $\bar{X}$ & $\mathrm{M}_{\mathrm{e}}$ & $\mathrm{M}_{\mathrm{o}}$ & $\mathrm{R}$ & $\mathrm{S}$ \\
\hline Experimental Class & 72 & 60 & 64.5 & 72 & 60 & 12 & 3.99 \\
\hline Control Class & 69 & 55 & 61.5 & 61 & 61 & 14 & 3.82 \\
\hline
\end{tabular}

Table 2 reveals that the experimental class that applied the Quick on the Draw learning strategy had better self-regulated learning results than the control class. The obtained mean value $(\underline{X})$ was 64.5 , and the mode $\left(\mathrm{M}_{\mathrm{o}}\right)$ was 60. It also produced a smaller range value than the control class, which was 12. Therefore, the self-regulated learning questionnaire results obtained by the experimental class were better than the control class.

After obtaining the mathematical concept understanding and self-regulated learning test results, the obtained data were analyzed. Data analysis is a method used to strengthen the effects of hypothesis testing or conclusions of the research. Then, the researchers performed the normality test, homogeneity test, and hypothetical test on the obtained data. If the data analyzed is normally distributed, then parametric statistical techniques can use. However, if the analyzed data is not normally distributed, then non-parametric statistical techniques should be used (Santoso, 2019).

The first step was performing the normality test using the KolmogorovSmirnov test on students' mathematical concept understanding and self-regulated learning. If the obtained value (p) is more than 0.05 , then the data is normally distributed. Table 3 contains the results of the normality test analysis.

Table 3. The results of the normality test on the mathematical concept understanding ability

\begin{tabular}{|l|c|c|c|}
\hline \multicolumn{1}{c}{ Class } & $\mathbf{p}-$ Value & $\mathbf{a}=\mathbf{0 . 0 5}$ & Decision \\
\hline Experimental Class & 0.104 & 0.05 & Normally Distributed \\
Control class & 0.155 & 0.05 & Normally Distributed \\
\hline
\end{tabular}

Based on Table 3, the normality test value on students' mathematical concept understanding ability at the significance level of $\mathrm{a}=0.05$ was $\mathrm{p}-$ value $>=0.05$. Therefore, the data obtained from the experimental class and the control class came from a normally distributed population. After that, the results of the normality test on selfregulated learning are presented in Table 4. 
DOI: https://doi.org/10.24127/ajpm.v10i1.3173

Table 4. The results of the normality test on self-regulated learning

\begin{tabular}{|l|l|c|c|}
\hline \multicolumn{1}{c|}{ Class } & $\mathbf{p}-$ value & $\mathbf{a}=\mathbf{0 . 0 5}$ & Decision \\
\hline Experiment Class & 0.130 & 0.05 & Normally Distributed \\
Control class & 0.122 & 0.05 & Normally Distributed \\
\hline
\end{tabular}

Based on Table 4, the normality test value on students' self-regulated learning at the significance level of $\mathrm{a}=0.05$ was $p-$ Value $>a=0.05$. Therefore, it can be concluded that the experimental class and the control class came from a normally distributed population.
The next step was performing the homogeneity tests on students' concept understanding ability and self-regulated learning. Tables 5 and 6 present the results of the homogeneity test calculation on students' mathematical concept understanding ability and self-regulated learning.

Table 5. The homogeneity test results on mathematical concept understanding ability and self-regulated learning

\begin{tabular}{ccc}
\hline Statistics & $\begin{array}{c}\text { Concept } \\
\text { Understanding }\end{array}$ & Self-Regulated Learning \\
\hline $\mathrm{p}-$ Value & 0.536 & $\mathrm{p}-$ Value $>0.05$ \\
Homogeneity & & 0.800 \\
Conclusion & & Homogeneous \\
\hline
\end{tabular}

Based on Table 5, it was known that the data were homogeneous because they matched the criteria where $p-$ Value $>$ $\alpha=0,05$. Since the data came from a population with a normal distribution and had the same population variance (homogeneous), the hypothesis testing could be performed.
A parametric test of Multivariate Analysis of Variance (MANOVA) was performed to test the hypothesis. The first test was done to test the influence between subjects or variables partially (Test of Between-Subjects Effects). The results of the partial test can be seen in Table 6 .

Table 6. The influence between subjects test (the test of between-subjects effects)

\begin{tabular}{|l|l|c|c|}
\hline \multicolumn{1}{|c|}{ MANOVA Hypothesis } & \multicolumn{1}{|c|}{ Ability } & p-value & Decision \\
\hline $\begin{array}{l}\text { Quick on the Draw } \\
\text { learning strategy }\end{array}$ & $\begin{array}{l}\text { Mathematical concept } \\
\text { understanding }\end{array}$ & 0.002 & $\mathrm{H}_{0}$ is rejected \\
& Self-regulated learning & 0.007 & $\mathrm{H}_{0}$ is rejected \\
\hline
\end{tabular}

Table 6 shows that the obtained $\mathrm{p}$ - value was 0.002 with a degree of significance of 0.05 . This result indicates that the $\mathrm{p}$ - value $<0.05$; thus, $\mathrm{H}_{0}$ was rejected, and $\mathrm{H}_{1}$ was accepted. Therefore, it can be concluded that the Quick on the Draw learning strategy on students' mathematical concept understanding was an effect.

The p-value of the self-regulated learning was 0.007 with a significance level of 0.05 . it can be seen that the $\mathrm{p}-$ value $<0.05$ so that $\mathrm{H}_{0}$ was rejected and $\mathrm{H}_{1}$ was accepted. In short, there was a significant effect of Quick on the Draw learning model on students' self-regulated learning.

Furthermore, the Multivariate test was done to see the effect of the learning strategy on students' mathematical concept understanding ability and selfregulated learning simultaneously. The results of Multivariate testing can be seen in Table 7. 
DOI: https://doi.org/10.24127/ajpm.v10i1.3173

Table 7. Multivariate testing

\begin{tabular}{|c|c|c|c|}
\hline \multicolumn{2}{|c|}{ MANOVA Hypotheses } & p-Value & Decision \\
\hline $\begin{array}{l}\text { Quick on the Draw learning } \\
\text { strategy }\end{array}$ & $\begin{array}{l}\text { Wilks' } \\
\text { Lambda }\end{array}$ & 0.000 & $\mathrm{H}_{0}$ is rejected \\
\hline
\end{tabular}

It can be seen in Table 7 that the obtained $\mathrm{p}$-value was 0,000 with a significance level of 0.05 . Therefore, $\mathrm{p}-$ value $<0.05$, so that $\mathrm{H}_{0}$ was rejected and $\mathrm{H}_{1}$ was accepted. It can be concluded that there was an effect of Quick on the Draw learning strategy on mathematical concept understanding ability and self-regulated learning simultaneously.

The results obtained were related to the previous research conducted by Huriyanti and Rosiyanti (Huriyanti \& Rosiyanti, 2017). They found that the Quick on the Draw learning strategy influenced students' motivation to learn mathematics (Huriyanti \& Rosiyanti, 2017). Furthermore, research by Aini and Irawati (Aini \& Irawati, 2019) discovered that the Quick on the Draw learning strategy increased students' activities and learning outcomes. Also, Damayanti (Damayanti et al., 2020) found that the Quick on the Draw learning strategy can improve students' mathematical communication skills.

Based on the research results, the

Quick on the Draw learning strategy affected the experimental class's mathematical concept understanding ability and self-regulated learning better than the control class that applied the conventional learning strategy. The difference was caused by the Quick on the Draw learning strategy had different characteristics from conventional learning strategies. One of the characteristics was the steps of the learning strategy. The Quick on the Draw learning strategy and conventional learning strategy had different learning steps.
The learning process in the Quick on the Draw learning strategy was started by holding a pretest to see students' initial abilities. Referring to the pretest's results, many students could not master the mathematical concept understanding ability and self-regulated learning. It was proven by the low value of each mathematical concept understanding and self-regulated learning indicator. There are seven indicators of concept understanding ability which include re-conveying concepts, classifying objects with specific properties according to the concepts, giving examples and not examples of concepts, developing necessary or sufficient conditions of a concept, presenting a concept in the form of a mathematical representation, using, utilizing, and choosing specific procedures or operations, and applying a mathematical concept in problemsolving. Unfortunately, many students could not master the indicators. The score of each indicator was poor and below the average.

Self-regulated learning has six indicators: determining standards and goals, self-instruction, regulating emotions, self-monitoring, selfevaluation, and self-determining contingencies. It turned out that many students could not master these indicators. The score of each indicator was low and below the average.

The students could be trained to master mathematical concept understanding ability and self-regulated learning through the Quick on the Draw learning strategy. 
The Quick on the Draw learning strategy steps consists of a preliminary activity stage, a core activity stage, and a closing stage. In the preliminary activity stage, the teacher performs apperception, conveys learning objectives, and explains the procedures of the Quick on the Draw learning strategy. At the core activity stage, the teacher divides students into three heterogeneous groups then asks them to discuss among group members regarding the source material. After preparing sets of questions, the teacher explains the rules for taking the question cards, then gives the signal "start" to the representatives of each group to take the question cards. Furthermore, students in each group are asked to solve the problem individually and then discuss their work within their groups. The next activity is asking each group to write down the results of the discussion into the worksheet to be collected and examined by the teacher. If the answer is correct, then the student may take the next card. However, if the answer is wrong, they must correct and discuss the answer again. The first group answers all (one set) of questions is declared as the winning group. These activities can train students' mathematical concept understanding ability and their self-regulated learning. In the closing activity, the teacher evaluates by giving assignments, asking students to make conclusions, providing information about the following material, and ending the lesson by saying a closing remark.

Based on the description of the Quick on the Draw learning strategy and conventional learning strategy, it can be seen that each learning strategy has its characteristics and advantages. However, the Quick on the Draw learning strategy effectively increases students' mathematical concept understanding ability and self-regulated learning compared to the conventional learning strategy. The Quick on the Draw learning strategy also makes students more focused in the group discussion process because the group discussion stages are well structured. Thus, the students could absorb the knowledge. If the students follow all steps correctly, they can understand and solve every mathematical problem well.

This research contributes to the educational institution to consider using the Quick on the Draw learning strategy in learning mathematics in particular and other learning in general. The results of this research are closely related to the performance of a teacher to develop competencies to achieve the learning objectives. Furthermore, this research also serves as a reference for applying Higher-Order Thinking Skill (HOTS) learning strategies, especially in mathematical concept understanding and self-regulated learning.

\section{CONCLUSION AND SUGGESTION}

Based on the results of the analysis and discussion, it can be concluded that the Quick on the Draw learning strategy affected students' mathematical concept understanding ability and self-regulated learning, either partially or simultaneously. The application of the Quick on the Draw learning strategy positively influenced students' mathematical concept understanding ability and self-regulated learning compared to the conventional learning strategy. Overall, the Quick on the Draw learning strategy applied in this research produced positive results. 


\section{REFERENCES}

Aini, S. D., \& Irawati, S. (2019). Strategi Pembelajaran Quick on the Draw untuk Meningkatkan Aktivitas dan Hasil Belajar Mahasiswa Pada Materi Interpolasi. Numerical: Jurnal Matematika Dan Pendidikan Matematika, 1(1), 19-30.

Alten, D. C. D. Van, Phielix, C., Janssen, J., \& Kester, L. (2020). Self-Regulated Learning Support In Flipped Learning Videos Enhances Learning Outcomes. Computers \& Education, $158,104000$. https://doi.org/10.1016/j.compedu.2 020.104000

Damayanti, R. R., Zulkarnain, I., \& Sari, A. (2020). Kemampuan Komunikasi Matematis Siswa Dalam Pembelajaran Matematika Menggunakan Model Quick on the Draw. EDU-MAT: Jurnal Pendidikan Matematika, 8(1), 5461.

https://doi.org/10.20527/edumat.v8i 1.8352

Diana, P., Marethi, I., \& Pamungkas, A. S. (2020). Kemampuan Pemahaman Konsep Matematis Siswa: Ditinjau dari Kategori Kecemasan Matematik. SJME (Supremum Journal of Mathematics Education), 4(1), 24. https://doi.org/10.35706/sjme.v4i1. 2033

Hodiyanto, H., \& Firdaus, M. (2020). the Self Regulated Learning, Habit of Mind, and Creativity As High Order Thinking Skills Predictors. AKSIOMA: Jurnal Program Studi Pendidikan Matematika, 9(1), 21. https://doi.org/10.24127/ajpm.v9i1. 2589

Hudaifah, F. (2020). Peran SelfRegulated Learning Di Era Pandemi Covid-19. Biormatika, 6(2), 76-84.
Huriyanti, L., \& Rosiyanti, H. (2017). Perbedaan motivasi belajar matematika siswa setelah menggunakan strategi pembelajaran quick on the draw. Fibonacci, 3(1), 65-76.

Inayatusufi, C., Hakim, L. El, \& Sari, P. (2020). Peningkatan Kemampuan Pemahaman Konsep Matematis melalui Model Kooperatif Tipe Scramble dengan Pendekatan Kontekstual Pada Materi Segiempat dan Segitiga di Kelas VII. Jurnal Riset Pendidikan Matematika Jakarta, 2(1), 28-37.

Jansen, R. S., Leeuwen, A. Van, Janssen, J., \& Jak, S. (2019). Self-Regulated Learning Partially Mediates the Effect of Self-Regulated Learning Interventions On Achievement in Higher Education: A MetaAnalysis. Educational Research Review, 28, 100292. https://doi.org/10.1016/j.edurev.201 9.100292

León, J., Núñez, J. L., \& Liew, J. (2014). Self-determination and STEM education: Effects of autonomy, motivation, and self-regulated learning on high school math achievement. Learning and Individual Differences, 43, 156163.

https://doi.org/10.1016/j.lindif.2015 .08 .017

Mulyati, S., \& Setiawan, I. (2019). Pengembangan Pembelajaran Ekonomi Pendekatan Konstruktivistik-Kontekstual Dengan Perspektif. Equilibrium: Jurnal Penelitian Pendidikan Dan Ekonomi, 16(1), 39-47.

Ntjalama, K. M., \& Murdiyanto, T. (2020). Penerapan Model Problem Based Learning untuk Meningkatkan Pemahaman Konsep Matematika Ditinjau dari Multiple 
DOI: https://doi.org/10.24127/ajpm.v10i1.3173

Intelligences Siswa. Jurnal Riset Pendidikan Matematika Jakarta, 2(2), 13-20.

Prameswari, L. A., \& Anistyasari, Y. (2019). Pengaruh Media Pembelajaran Bergerak Terhadap Self-Regulated Learning Dan Hasil Belajar Siswa Pada Mata Pelajaran Sistem Komputer. Jurnal IT-Edu, 3(2), 44-51.

Romadon, S., \& Mahmudi, A. (2019). Penerapan Pendekatan Penemuan Terbimbing Untuk Meningkatkan Kemampuan Pemahaman Konsep Matematis Siswa. AKSIOMA: Jurnal Program Studi Pendidikan Matematika, 8(1), 58-64. https://doi.org/10.24127/ajpm.v8i1. 1684

Sagala, R., Umam, R., Thahir, A., Saregar, A., \& Wardani, I. (2019). The Effectiveness of Stem-Based on Gender Differences: The Impact of Physics Concept Understanding. European Journal of Educational Research, 8(3), 753-761. https://doi.org/10.12973/eujer.8.3.753

Santoso, S. (2019). Mahir Statistik Parametrik. Jakarta: Elex Media Komputindo.

Saputra, W. N. E., Da Costa, A., \& Alhadi, S. (2018). Creative Solution Focused Counseling Models (CSFCM): Strategi Kreatif untuk Mengembangkan Self-regulated Learning Siswa. Jurnal Kajian Bimbingan Dan Konseling, 3(4), 162-170.

https://doi.org/10.17977/um001v3i4 2018p162
Subekhi, A. I., \& Pujiastuti, H. (2020). Analisis Kemampuan Matematika Dasar Ditinjau Dari Self-Regulated Learning: Studi Kasus Pada Mahasiswa S1 Farmasi Universitas Mathla'ul Anwar Pandeglang Banten. JES-MAT, 6(1), 55-64.

Sukaesih, E. S., Indiati, I., \& Purwosetiyono, F. X. D. (2020). Kemampuan Pemahaman Konsep Matematis Siswa dalam Memecahkan Masalah Kontekstual Ditinjau dari Komunikasi Matematis Siswa. Imajiner: Jurnal Matematika Dan Pendidikan Matematika, 2(4), 310-320.

Sundary, P., Jatmiko, A., \& Widyastuti, R. (2020). Metaphorical Thinking Approach With Google Classroom: Its Effect Towards Students' Understanding Of Mathematical Concept Skills. Indonesian Journal of Science and Mathematics Education, 3(1), 37-47.

Utami, S. S. A., Ramdani, H. C., \& Khusaini. (2020). Pengaruh Gender, Status Bekerja, Dan Self-Regulated Learning Terhadap Prestasi Akademik Mahasiswa. Jurnal Program Studi Pendidikan Ekonomi, 1(1), 18-24.

Winata, R., \& Friantini, R. N. (2020). Kemampuan Pemahaman Konsep Matematika Siswa Ditinjau Dari Minat Belajar Dan Gender. AlphaMath, 6(1), 1-13. 